\title{
Surveying immigrants in Southern Europe: Spanish and Italian strategies in comparative perspective
}

\author{
Inmaculada Serrano Sanguilinda ${ }^{1}$, Elisa Barbiano di Belgiojoso ${ }^{2 *}$, Amparo González Ferrer ${ }^{1}$, \\ Stefania Maria Lorenza Rimoldi ${ }^{2}$ and Gian Carlo Blangiardo ${ }^{2}$
}

\author{
* Correspondence: \\ elisa.barbiano@unimib.it \\ ¿Università degli Studi di \\ Milano-Bicocca, Via degli Arcimboldi \\ 8, 20126 Milan, Italy \\ Full list of author information is \\ available at the end of the article
}

\begin{abstract}
Italy and Spain, as countries of recent immigration and high irregularity rates, have struggled to adapt their statistical system, especially their population registers, to adequately reflect the presence of an increasing number of immigrants in their territory. The population registers of the two countries have adapted differently to these changing realities: Spain introduced significant improvements in Padrón which have increased its coverage and accuracy. This is still not the case in Italy, making it necessary to resort to non-random sampling methods. The paper discusses the methodological implications of these differences and evaluates different methodological solutions based on both random and non-random sampling methods in both countries.
\end{abstract}

Keywords: Sampling migrants, Population register, Italy, Spain

\section{Introduction}

Achieving a representative sample of immigrant populations faces two fundamental problems: the availability of sample frames that correctly identify these populations and elevated fieldwork costs due to territorial dispersion, among other factors. Population registers provide the most updated and comprehensive sample frame on a country's population, but they do not always contain the necessary categories to identify immigrant population, or their coverage of this target population is imperfect, which also hinders the representativeness and unbiased nature of samples obtained from these registers. This article focuses on the comparison of two similar migration contexts, Spain and Italy, and the specific challenges these countries encounter as recent destination countries with high levels of irregularity among their immigrant population. The population registers in both countries, Padrón and Anagrafe, respectively, have adapted differently to these changing realities. The paper discusses these differences and analyzes the methodological implications for sampling immigrant population in both countries and in comparative perspective.

The paper proceeds as follows: Short description of the immigration to Italy and Spain briefly describes recent immigration to both Italy and Spain. Padrón and Anagrafe: statistical categories available to identify immigrant population discusses the statistical categories needed for identifying migrant population in the contexts of

(C) The Author(s). 2017 Open Access This article is distributed under the terms of the Creative Commons Attribution 4.0 International License (http://creativecommons.org/licenses/by/4.0/), which permits unrestricted use, distribution, and reproduction in any medium, provided you give appropriate credit to the original author(s) and the source, provide a link to the Creative Commons license, and indicate if changes were made. 
recent migration, and evaluates the Padrón and Anagrafe along these lines. Padrón and Anagrafe: coverage, accuracy and access discusses additional issues of coverage, quality and access for the Padrón and Anagrafe. Implications for register-based probability sampling of immigrants in Spain and Italy analyzes the challenges and limitations of registerbased sampling in both countries, assessing the outcomes of some empirical experiences and Alternative sampling methods for immigrants in Spain and Italy evaluates the experience of different alternative sampling methods. Discussion and conclusions concludes with a discussion on the implications of the Anagrafe and Padrón characteristics and an evaluation of the different methodological solutions presented.

\section{Short description of the immigration to Italy and Spain}

Italy and Spain, which had long been emigration countries, have converted into immigrant nations, with an increasing number of immigrants coming from less developed countries (Bonifazi, 2013; Strozza, 2004; Arango, 2000). In Spain, the foreign-born population, which represented less than $2.5 \%$ of the total population at the end of the $90 \mathrm{~s}$, increased to more than 6 million people (15\% of total) in 2016, according to the data from the Population Register (National Statistical Institute, INE). That same year, the foreign population legally residing in Italy amounted to more than 5 million people (approximately $8 \%$ of total population), compared to a total of less than $3 \%$ at the beginning of the century (Population Register, Italian National Institute for Statistics, Istat). ${ }^{1}$ If irregular (non-EU) migrants $(435,000)$ and regular but unregistered migrants $(410,000$ - mainly from EU countries) are added, the total foreign population in Italy reaches approximately 6 million people, according to the latest estimates by Blangiardo (2016). ${ }^{2}$

Among non-EU residents, a high incidence of irregularity has been traditionally identified as a defining characteristic of the immigration regime in both countries. This is largely the result of relatively loose visa policies and large informal sectors in the labour market (Arango \& Finotelli, 2009; Cebolla \& González-Ferrer, 2008; Reyneri, 1998; Strozza, 2004). However, successive regularization programs ${ }^{3}$ have substantially reduced this irregularity rates: in Spain, from 60\% in 2003 to 13\% in 2008 (Cebolla \& González-Ferrer, 2013), and in Italy, from 62\% in 1990 to 7\% in 2016 (Blangiardo, 2016). Additionally, the proportion of non-EU foreigners with a permanent residence permit increased in Spain from 36\% in 2008 to $68 \%$ in 2012, which clearly illustrates the settlement process of the immigrant population in Spain (Cebolla \& González-Ferrer, 2013). In Italy, 45.7\% of the foreign resident population in 2015 had arrived before 2003, meaning they have been living in the country for more than 10 years, and 57\% have a permanent residence permit (Istat, 2015).

The economic crisis significantly changed the migration dynamics. In Spain, emigration progressively increased for both immigrants and natives, especially since 2011 (Domingo \& Blanes, 2015; González-Ferrer, 2013), and immigration has substantially declined since 2008, although annual entries remain still at high levels (more than 250,000 in 2013). In Italy, net migration started to fall in $2008(450,000)$ until in 2014 it reaches the same level registered at the turn of the century (143,000 units) (Blangiardo, 2015).

\section{Padrón and Anagrafe: statistical categories available to identify immigrant population}

Immigrant populations living in a particular country at a certain moment can be identified using two main criteria: country of birth (foreign-born vs natives) or citizenship 
(non-citizens vs citizens). Country of birth offers the advantage of being a stable, time-constant individual characteristic, whereas citizenship can be multiple and it can change over time, which may disguise migrant status. However, statistics based on citizenship allow to better distinguish between foreign migration inflows and returns of national citizens who migrated abroad (Strozza, Natale, Todisco, \& Ballacci, 2002). But neither of these categories can fully identify the immigrant population in a country (Jacobs, et al., 2009; Méndez \& Font, 2013), since the two categories do not perfectly overlap, and both are relevant to identify a segment of the population with peculiar legal and social links to the host country.

In Italy, official statistics are generally organized according to the concept of citizenship. ${ }^{4}$ Non-EU migration inflows are counted through permits of stay, which are obviously granted only to foreign citizens. Inflows of EU citizens, as well as stocks of the overall population, are counted through the population register (Anagrafe). ${ }^{5}$ In Spain, citizenship was also traditionally the main concept organizing data collection in the field of migration but, as immigration flows increased, information on country of birth has become increasingly available. The Municipal Register (Padrón) first included information on country of birth in 1996, although this information was not exploited in the data periodically published by the Statistics Office (INE) until years later (see more in González-Ferrer, 2009). The Statistics on Residence Permits did not include this information until 2005. Currently, the INE systematically includes this variable in most of its statistical operations, together with the variable of citizenship.

Opting for the citizenship criterion to organize immigration figures seems reasonable in Italy considering the quite restrictive laws on the acquisition of the Italian citizenship (10 years of residence, marriage with an Italian and 2 years of residence, and by formal request after turning 18 years old for foreigners born in Italy) and the long emigration experience of Italians. However, as the size and length of settlement of international immigrants in Italy increase, acquisitions of Italian citizenship have also increased from about 50,000 in 2008 to 200,000 in 2016 (Blangiardo, 2015; Istat, Demographic Statistics). Moreover, by now the return migration of Italian emigrants is almost negligible.

The systematic incorporation of the country of birth variable in Spanish statistics must be particularly welcome considering the rules regulating the access to Spanish citizenship. Even if the general rule is the same as in Italy (10 years of residence) Latin Americans, which represent a large proportion of the foreign-born population in Spain (56\% of the non-EU citizens) are allowed to apply for Spanish citizenship after 2 years of continuous legal residence in Spain. A total of 1.270 million persons have in fact obtained the Spanish nationality between 1996 and 2015 (Ministerio de Empleo y Seguridad Social). In this context, having statistical information on immigrants only on the basis of current citizenship would represent a major limitation.

\section{Padrón and Anagrafe: coverage, accuracy and access Coverage}

Italy and Spain are characterized by high levels of irregularity among their immigrant population, even if those levels have descended in recent years, making it a particularly salient issue. In Italy, nonetheless - as it happens in most countries around the world irregular migrants cannot get registered in Anagrafe. In contrast, since 1996 Spanish 
municipalities not only have the possibility to register every person living in their territory regardless of their administrative status, but also the obligation to do so.

Coverage is also affected by the incentives and barriers to registration. In Italy, the registration in the Anagrafe is mandatory for both non-EU foreign citizens (with residence permit) and EU citizens (after 3 months of presence), but this is not an automatic process. The registration, in fact, requires a voluntary inscription that bears little or no incentives, which leads to significant under-registration - amounting to 410,000 individuals in 2015, particularly among EU migrants (Blangiardo, 2016). In contrast, the registration in the Spanish Padrón counts with very strong incentives since the year 2000, when the Law 4/2000 on the Rights of Foreigners and their Social Integration into Spanish Society imposed the empadronamiento (registration in the Padrón) as the only legal requirement to access public health care and other public services such as enrollment in primary schools. In addition to this, the regularisation program that accompanied the legal reform - and all other regularisations implemented since - accepted the certificate of empadronamiento as a proof of the length of residence in Spain, which especially encouraged the registration of undocumented migrants. Last but not least, most municipalities carried out campaigns to promote the empadronamiento of foreign residents in those early years, since the budget they receive from the central government depends precisely on their total population as counted in the Padrón.

\section{Accuracy}

The accuracy and reliability of population registers also depends on the timely deregistration of persons when they leave the country - as well as notification of changes in their residence within it. This general problem is particularly relevant in the case of migrants, who are a more mobile population (Reichel \& Morales, 2017). In both Italy and Spain de-registration is not mandatory, and there are no particular incentives for migrants to deregister when they leave permanently. This situation results in over-registration, reducing the reliability of these registers to identify (and sample) immigrant-origin population.

In Italy, cleaning operations of the Anagrafe are conducted only after every Census, when registrations and (above all) de-registrations 'd'ufficio' are possible. Spain additionally introduced in 2005 an 'expiry procedure' (caducidad padronal) implemented for the first time in 2007, that requires all non-EU foreigners without a permanent residence permit to renew their registration in the Padrón every 2 years. After its first implementation, the new population figures for January 1st, 2007 reflected that approximately a quarter million non-EU foreigners had been deregistered 'ex officio' (González-Ferrer, 2009). ${ }^{6}$ Secondly, a periodical residence check (comprobación periódica de la residencia) to be conducted every 5 years was introduced for EU citizens and permanent non-EU residents in 2011. This procedure was implemented for the first time in 2013: more than 400,000 foreigners disappeared from the Padrón, 87\% of which were EU citizens (mainly from Germany, UK and France) (Ródenas, 2012).

\section{Access}

In Spain, it is feasible to draw individual probability samples for both foreigners and foreign born individuals living in the country from the Padrón. Individual samples from 
the Padrón can be requested from the National Statistical Institute (INE). However, official support from some unit of the Spanish Public Administration is required and public universities, even Spanish ones, do not qualify as such. Public universities can benefit though from a $15 \%$ discount in the final price for the sample. Access to the Anagrafe for research is strictly limited, since only municipalities are entitled to manage it: anonymous records for research sometimes can be obtained at the discretion of the public officers. Even the Italian Institute of Statistics (Istat) does not have access to the individual records, and the selection of the sample in the case of surveys is carried out by the municipalities.

\section{Implications for register-based probability sampling of immigrants in Spain and Italy}

Italy: the limitations of the Anagrafe to sample immigrants

In Italy, the coverage of Anagrafe is limited to the subgroup of foreigners (but not foreign-born) who have voluntarily registered in the Anagrafe and, in the case of nonEU citizens this excludes migrants without a residence permit. This limited coverage has led various authors (Natale \& Strozza, 1997; Strozza, 2004; Blangiardo, 1996) to discard register-based probabilistic sampling.

However, Istat still uses this approach and has conducted several surveys on households including at least one foreign member (see Table 1). These surveys are of crucial importance to deepen our knowledge of the foreign population living in Italy and to fill statistical gaps between censuses. However, it is necessary to bear in mind its significant limitations.

Most importantly, sampling from the population register leads to selecting only regular and resident migrants, which are the most stable segment of the population of interest (e.g. migrants with a longer length of stay and more frequently reunited with their relatives). The resulting samples will be less useful in studying the less stable population that goes unregistered in the Anagrafe (recent arrivals, irregular situation or short-term migrants) ${ }^{7}$

Additionally, the coverage and accuracy of the register are also imperfect for the more stable population, due to the voluntary nature of registration and de-registration. Inaccuracy in the register also leads to increased non-contact rates. For instance, in the "Social condition and integration of foreign citizens" surveys, the final sample of households ended up being substantially smaller than initially expected in the sampling design (9553 compared to 12,269). This was so despite the fact that, in order to guarantee a sufficient sample size, the number of selected households was three times the theoretical sample size: each sample unit had three possible alternatives (similar with respect to citizenship, geographic residence and household size) to be used in case of the impossibility of contacting the first household (Istat, 2016).

\section{Spain: the challenges of sampling immigrants from the Padrón}

In Spain, the coverage of Padrón is more comprehensive, including both foreign-born and foreigners, and both regular and irregular (non-EU) migrants. Furthermore, there are strong incentives to register in the Padrón for all members of this population, including irregular migrants. But even if an adequate sample frame is available, the 


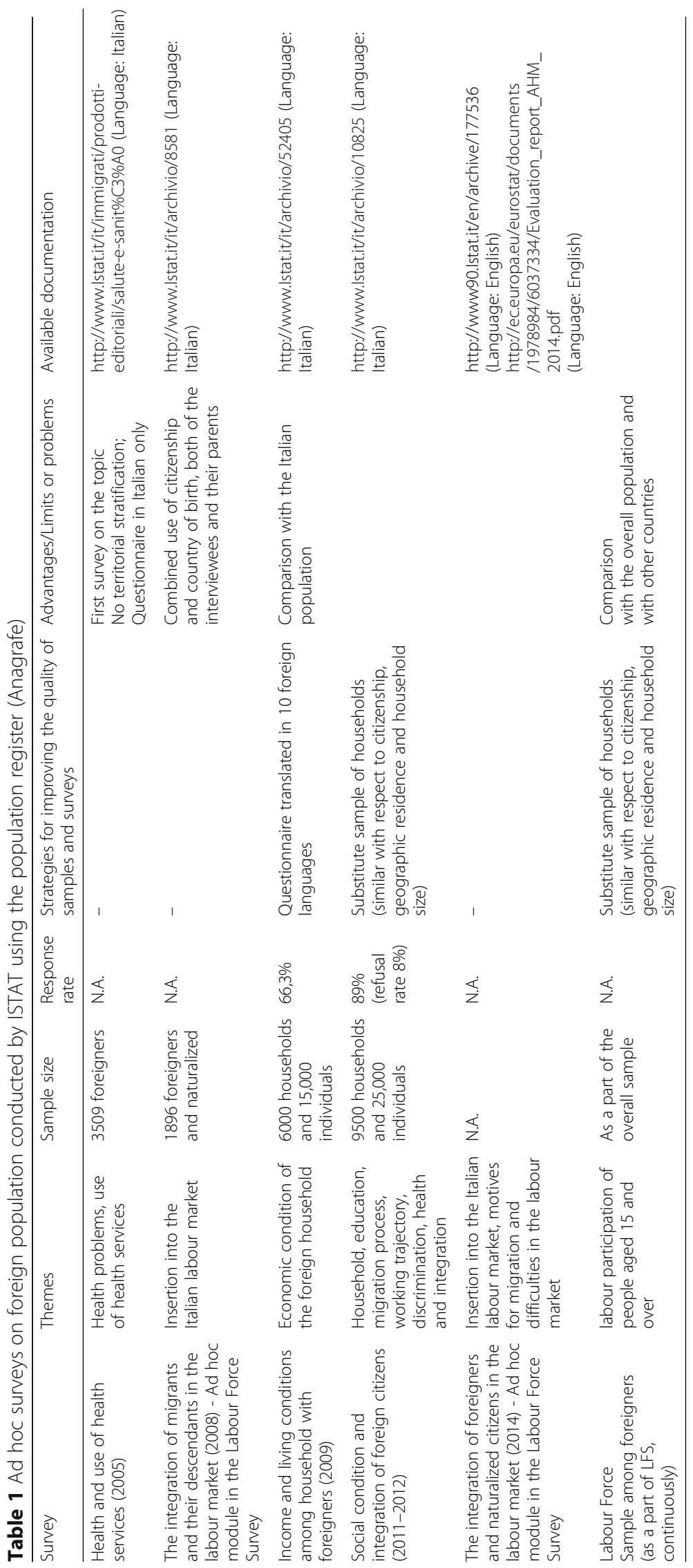


problem of elevated costs of fieldwork remains - due to the relatively small-size of migrant populations scattered across the territory, relative mobility and vulnerability (Reichel \& Morales, 2017). This difficulty is compounded when the sample frame is inaccurate due to a lack of de-registration or notifications of change of residence, which affects contact rates (and might potentially introduce biases in the final sample). Deregistration is voluntary and no particular incentives to do it exist in Spain either. However, the two corrective procedures - the 'expiry procedure' for non-EU nonpermanent foreign residents and the 'periodical residence check' for EU citizens-, which fully deployed their effects in 2006/7 and 2013 respectively, should have increased the reliability of the registry and lead to relatively improved contact rates.

The INE was the first institution to use the Padrón to carry out an individual probability sample to survey immigrants in Spain (National Immigrant Survey, ENI 2007). More focused immigrant surveys have been conducted as well by specialized research teams with less resources and more specific goals, often focused on particular origin groups and/or limited geographical areas. The most relevant ones are summarized in Table 2.

The first pilot for ENI was carried out in 2006, before the effects of the 'expiry procedure' were fully reflected in Padrón files from which the samples are drawn. The ENI pilot in fact revealed an elevated rate of non-contacts (36.2\%), mainly because the selected person had moved to another address (19.4\%). INE then decided to implement an alternative strategy in which the sampling unit was not the foreign-born individual but dwellings with at least one foreign-born occupant, also allowing the replacement of dwellings from a substitute sample (Duque, Ballano, \& Perez, 2013). ${ }^{8}$ Almost at the same time, the Localmutidem survey was also conducted, aiming to sample $900 \mathrm{mi}$ grants from Morocco and the Andean region. After encountering difficulties to locate individuals, with non-contact rates reaching 59\% (depending on the origin group), the Localmultidem survey also opted for expanding the sampling units from individuals to dwellings and adjacent dwellings. ${ }^{9}$

All other surveys in Table 2 were carried out once the first cleaning of the Padrón resulting from the 'expiry procedure' for non-EU migrants was fully implemented ${ }^{10}$, and all of them achieved their final numerical targets by applying an exclusively individual random sampling based on the Padrón. Still, non-contact rates remained elevated and different strategies were applied in order to maintain the survey costs within reasonable limits due also to territorial dispersion. For instance, in the case of ICS 2012 - aiming to sample at least 400 migrants in Madrid and Barcelona, respectively - the sample was clustered by neighbourhood code and selection was proportional to the size of the target population in the cluster, in order to reduce the time and money implied by an individual sample very dispersed throughout the territory. The results are deemed representative of the target population aside from random sampling errors or any biases that might be introduced by non-response (Reichel \& Morales, 2017; Morales et al., 2012).

The MESE survey ${ }^{11}$ - aiming to sample 400 Senegalese-born immigrants - faced particular challenges due to the demanding nature of its biographical questionnaire, which took on average 83 min to complete ${ }^{12}$ and the peculiarity of its target population. Senegalese migrants are one of the most recent and vulnerable immigrant groups in Spain: they have a high irregularity rate (31,6\% in 2008), they intensely concentrate in precarious jobs (Obućina, 2013) - which makes them more susceptible to 


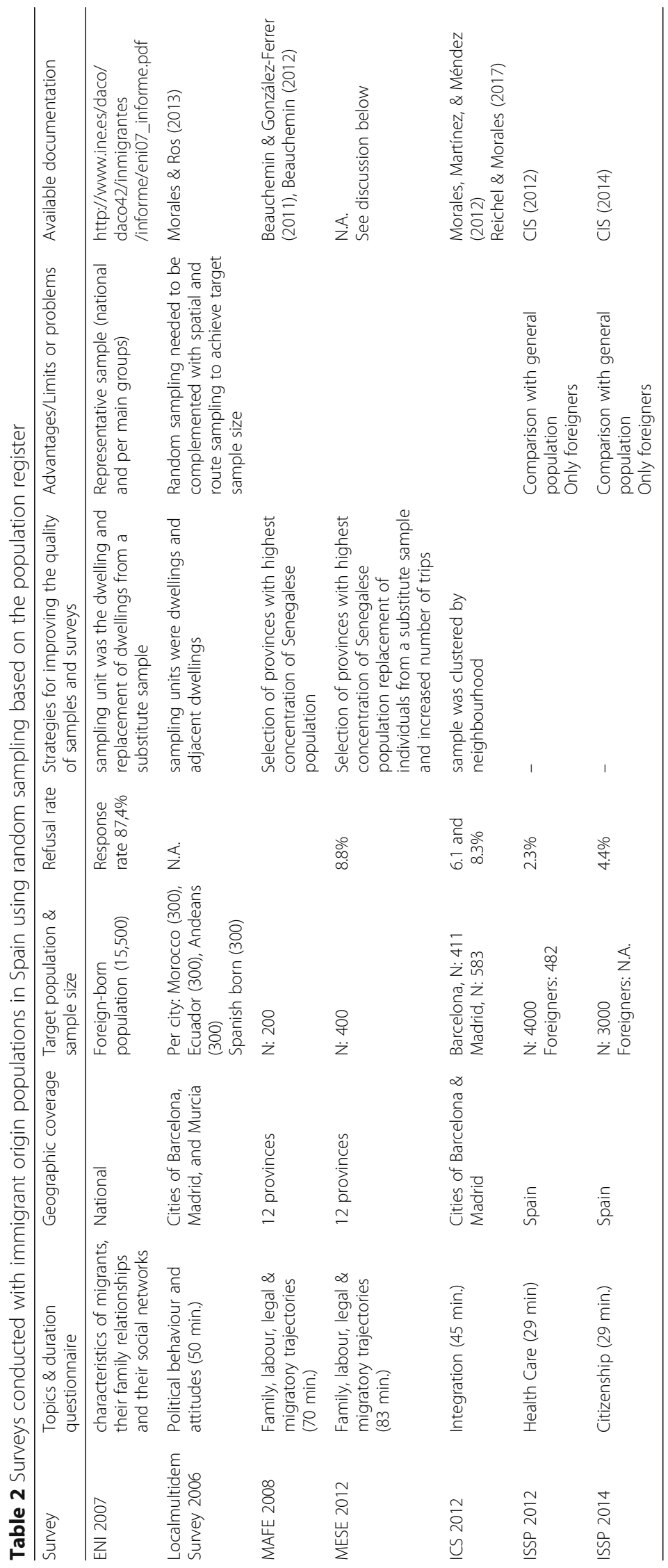


internal mobility - and they are more residentially segregated than other groups (Díaz Hernández, Domínguez Mujica, \& Parreño Castellano, 2010). All these factors are expected to produce high non-contact and refusal rates. The MESE sample was also designed to be directly proportional to the actual distribution of the Senegalese born population in the selected provinces, and as a result of this, it included a nonnegligible number of municipalities with only one or two contacts, largely in rural areas. These highly dispersed contacts seemingly raised the cost of fieldwork. ${ }^{13}$ However, finding individuals in rural areas and obtaining a positive response to participate was actually much easier than in urban areas, which needs to be taken into account when assessing the pros and cons of geographical dispersion of immigrant samples.

In order to deal with the double challenge of high non-contact rates (particularly as a result of the high mobility of the population, moving within the territory following job opportunities and visiting Senegal as well) and dispersion of the sample, the MESE team introduced more flexibility in contacts replacement. When visiting a particular location within their assigned area, and if unable to find the individuals initially sampled, the interviewers were allowed to try visiting those replacements who lived nearby, as far as gender and age group was the same. Additionally, the number of geographical trips allowed for each interviewer was increased, so that they could exhaust the number of visits per contact and the contact list provided by Padrón.

MESE required, on average, 2.8 contacts from the Padrón sample to complete one interview, compared to 2.7 in ICS (Morales et al., 2012), 2.3 in ISSP 2012 (CIS, 2012), and 3.4 in ISSP 2014 (CIS, 2014); therefore, quite in line with previous studies that addressed the overall immigrant population, and not just one of most vulnerable groups within it. The same happened with regard to the non-contact ${ }^{14}$ and refusal rates (see Table 2) in spite of a much longer and complex questionnaire in MESE and, in principle, a more difficult target population. ${ }^{15}$

\section{Alternative sampling methods for immigrants in Spain and Italy}

The use of population lists for sampling is a gold standard for obtaining representative probabilistic samples (Reichel \& Morales, 2017). However, when population lists are not available or cannot adequately identify the target population, alternative sampling methods can be used. ${ }^{16}$ This is the case of Italy, where the lack of an exhaustive list of the target population (and the inaccessibility of the Anagrafe) led researchers since the 1980s to design and employ sampling strategies specific to surveying migrants (Natale \& Strozza, 1997; Strozza, 2004; Blangiardo, 1996; Birindelli \& Blangiardo, 2010). In Spain, where the Padrón constitutes a proper sample frame, researchers have kept turning to alternative (cheaper) sampling methods due to the financial and administrative barriers to obtain individual samples, and to the high cost and uncertainty associated with registerbased random sampling.

The application of these methods faces similar challenges in these very similar contexts: ensuring the representativeness and adequacy of the sample, and again keeping the costs of sampling under control. Below we discuss the different methodologies and outcomes of different empirical experiences conducted in Italy and Spain, paying particular attention to the "Centre sampling technique" (CS), which has proved to be a very effective approach for addressing the Italian situation with many immigrants not registered in the Anagrafe. 
Other alternative sampling methods applied in Italy and Spain: outcomes and assessment Table 3 describes the main methodologies applied in Italy and Spain, and their corresponding empirical experiences. The limitations of these methodologies and experiences are discussed below.

The application of the snowball method, one of the most traditional non-random methodologies, presents some difficulties in determining the initial list and thus risks introducing significant biases, and the probability of inclusion in the sample is unknown. Moreover, the assumption of full network connectivity implies that if members of a rare population do not know each other they will be excluded by the sample (Reichel \& Morales, 2017; Natale \& Strozza, 1997). Attrition rates can also be high (increasing fieldwork costs) since the methodology relies on obtaining contacts for other migrants and being able to contact them later (McKenzie \& Mistiaen, 2009). The respondent driven sampling, similarly to snowball, implies relevant bias risks (Beauchemin \& González-Ferrer, 2011). In the experience of the Romanian Communities (Sandu, 2009) the sample over-represented men, especially in the age group 30-39. The residential units method was introduced by Casacchia and Strozza (1990) at the beginning of the 1990s in Italy and its application was successful in small and medium cities of some Italian Region, but it failed in big cities due to the difficulties to locate the apartments and contacts indicated with the snowball question (Natale \& Strozza, 1997). Quota sampling based on snow-balling was used in the MAFE survey (2008) in Italy - and partially in Spain. The authors find significant selection biases at origin (by age and socio-economic status) and, interestingly, much higher different response rates in Italy than in Spain. ${ }^{17}$ The authors reject the hypotheses of different implementing agencies or higher rates of irregularity in Italy, and propose that the particular political context at the time in Italy increased mistrust among respondents. Random routes have also been implemented to survey migrant population in Spain, but have only been successful used in combination with spatial sampling, the methodology most similar to the CS - see discussion below in the Localmultidem project. Spatial sampling produced low refusal rates and, overall, the socio-demographic profile of the final sample was quite similar to that of the ENI 2007. Substantive analyses also found no significant effect of the sampling method on a number of different variables related to the socio-political attitudes and behaviours of the respondents (Morales, Anduiza, Rodríguez \& San Martín, 2008).

\section{Advantages and limitations of the "Centre sampling technique" (CS) for sampling immigrants} in Italy

In the early 1990s, Blangiardo (1996) introduced the "Centre sampling technique" (CS). The CS is a probabilistic multi-level sample method specifically designed to collect information on a representative sample of migrants when a (complete) list of the target population is not available, and the total number of the population is unknown (Baio, Blangiardo, \& Blangiardo, 2011). The rationale of the CS is that migrants, during their everyday life, frequent a range of 'aggregation centres' (such as immigrant specific services, phone centres, churches, etc.), which can be used as first level unit of analysis to select migrants (the second level unit). The CS methodology provides a scheme to estimate a set of weights to correct the initial probability of inclusion in the sample (Fasani, 2008; Kraler \& Vogel, 2008; Vogel \& Kovacheva, 2008). 


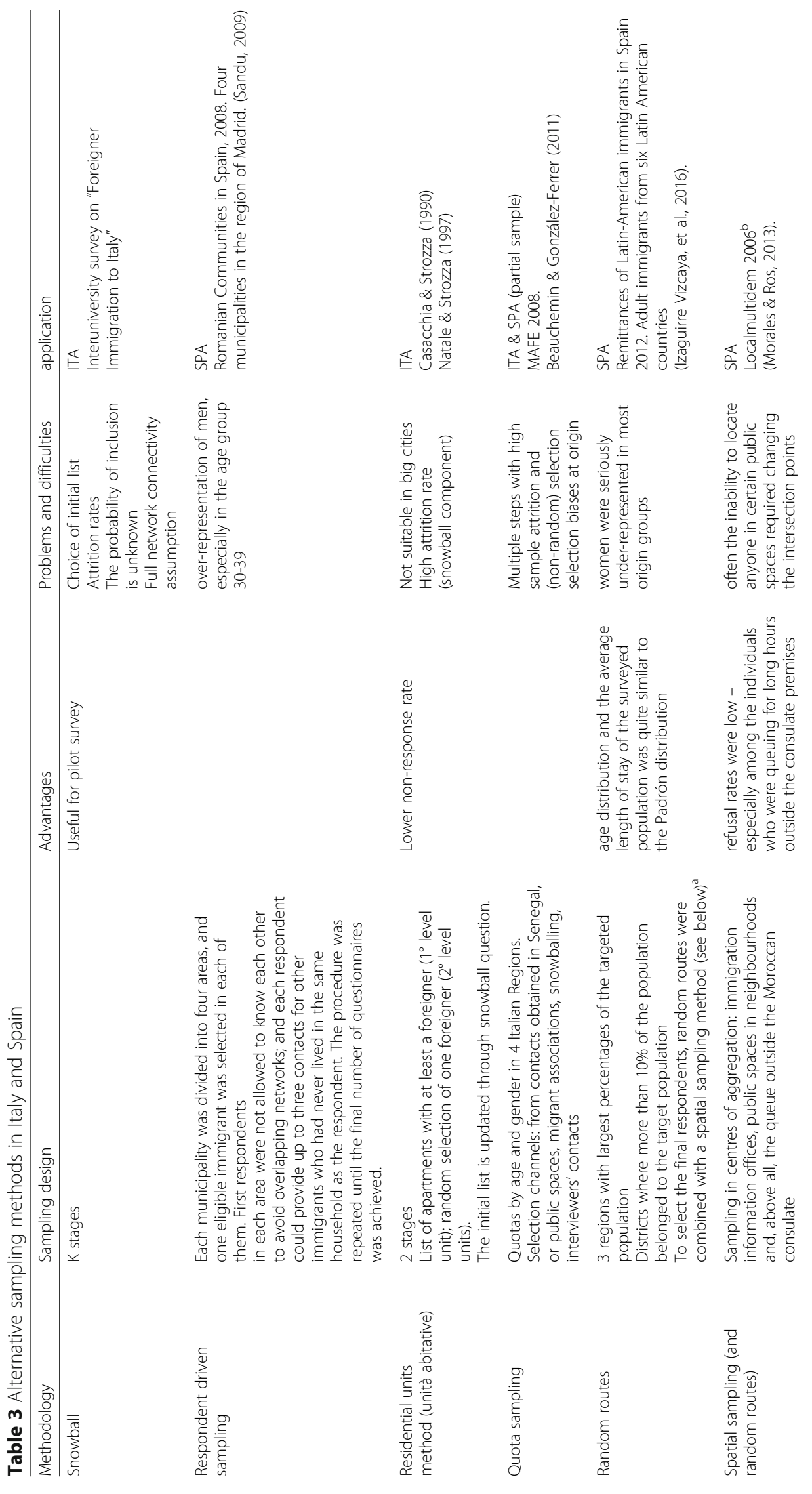




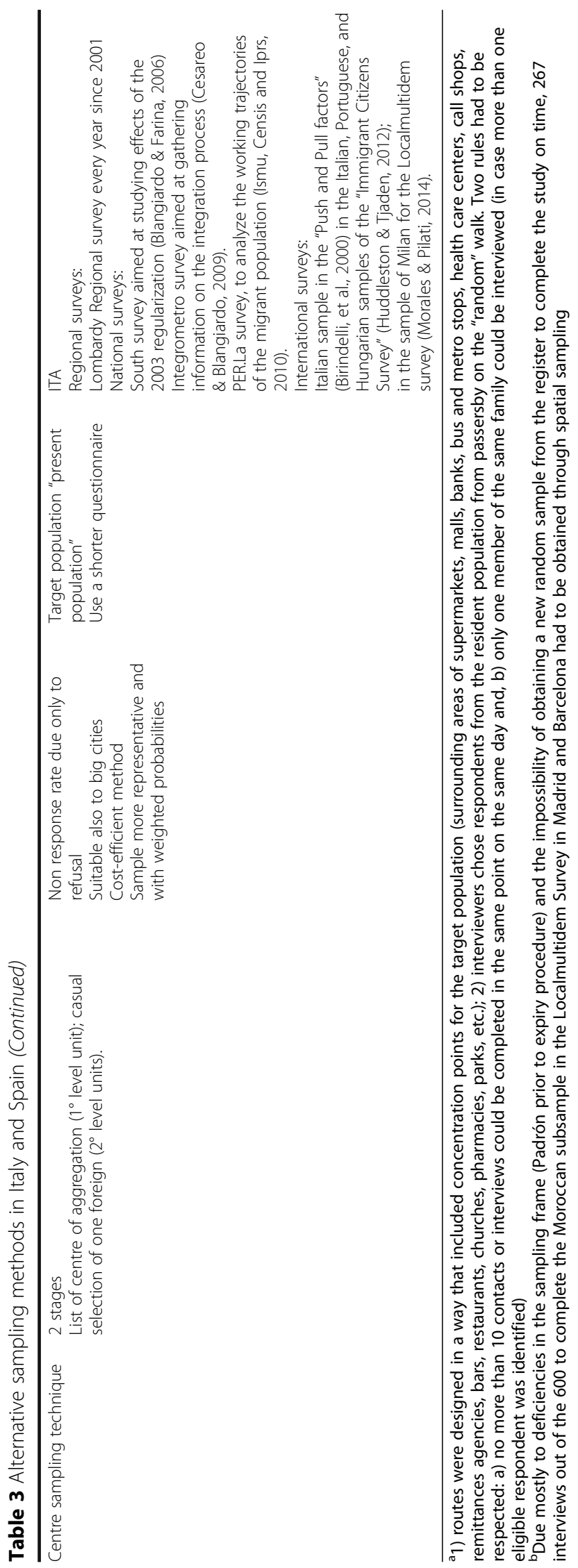


Based on the evaluation of these experiences, different experts consider the estimates based on the CS to be the most accurate and reliable for Italy (Fasani, 2008; Mecatti \& Migliorati, 2003; Blangiardo, 2008). In particular, the CS method provides reliable estimates of the percentage of registered foreigners in Anagrafe at the time of the survey (i.e. the rate of residents per 100 presents), and also the rate of foreigners with regular status with respect to residence (i.e. the rate of regulars per 100 presents) ${ }^{18}$ Furthermore, the estimations of irregular migrants produced after the 2003 regularization were successfully compared with the number of applicants for amnesty in 2006 (Barbiano di Belgiojoso \& Rimoldi, 2007; Accetturo \& Infante, 2013).

The main limitation of the CS is related to the composition of the target population by nationality: communities which are more closed and with lower levels of social participation are more difficult to detect and smaller communities have lower probabilities of being captured by the list of centres identified. For correcting this issue, the identification of the list of centres is a crucial point. It is necessary to identify the centres with a preliminary analysis of the environmental and socio-economic context, so that the set of centres is adequately heterogeneous and so that every subject in the universe is, at least theoretically, reachable at one of the selected centres. ${ }^{19}$ The CS strategy seems to guarantee better results when the origin mix in the immigrant population remains relatively stable over time. ${ }^{20}$

In terms of keeping the sampling costs low, a good level of cooperation among the selected respondents has also been found, compared with other surveys (Méndez \& Font, 2013), and the non- response rate is about $30 \%$ on average.

\section{Discussion and conclusions}

The use of population registers for sampling is a gold standard for obtaining representative probabilistic samples (Reichel \& Morales, 2017), however they do not always contain the necessary categories to identify immigrant population, or their coverage of this target population is imperfect, which also hinders the representativeness and unbiased nature of samples obtained from these registers. This article focuses on the specific challenges to sample immigrant population in two recent destination countries, Spain and Italy, which furthermore register high levels of irregularity.

The Padrón in Spain seems to have adapted much better to the new migratory circumstances of the country, by incorporating the category of country of birth, enabling the registration of irregular migrants and providing strong incentives for the registration of the migrant population in general, and irregular migrants in particular. This is not the case of Anagrafe, where the available statistical categories are more limited (only citizenship, but not country of birth), undocumented migrants are excluded from the register, and there is a lack of incentives for registration. The implications of these limitations are significant for the correct identification and characterization of the migrant population in Italy, as well as for conducting comparative analyses with the Spanish or other similar cases.

First, the availability of both country of birth and citizenship criteria to identify the immigrant population is particularly desirable in contexts where the frontier between immigrants and natives, and between foreigners and nationals become blurred due to increasing numbers of naturalised residents, a growing second generation population and the return of past and recent emigrants, which is the case for both Italy and 
Spain (Blangiardo, 2016; Martín-Pérez \& Moreno-Fuentes, 2012; González-Ferrer \& Trilla, 2015).

Second, irregular migrants are a particularly vulnerable segment of the migrant population, of crucial importance for the integration process and the political debate; and at the same time particularly hard-to-reach and invisible for the administration. For these reasons, the identification and analysis of irregular migrants is one of the most challenging aspects of migration studies, and their exclusion from the Anagrafe is a significant limitation, particularly in a context of with relatively high irregularity rates. In contrast, the Spanish Padrón is quite a exceptional source worldwide concerning the statistical coverage of foreign population in an irregular administrative situation, which allows the inclusion of this vulnerable segment of the population in probabilistic register-based samples.

Finally, the lack of incentives for registration in Anagrafe also leads to a significant under-registration (and thus under-estimation) of EU and regular non-EU migrants. The overall gap in coverage in Anagrafe - including irregular and unregistered migrants - currently amounts to approximately $15 \%$ of relevant individuals based on the estimates provided by Blangiardo (2016). As a result of this lack of a comprehensive listing, register-based sampling is not recommended in Italy. Istat continues nonetheless to use the Anagrafe to conduct immigration surveys, and such surveys are of crucial importance to deepen our knowledge of the foreign population living in Italy and to fill statistical gaps between censuses. However, it is necessary to bear in mind its significant limitations. Most importantly, sampling from the population register leads to selecting only regular and resident migrants, which are the most stable segment of the population of interest (e.g. migrants with a longer length of stay and more frequently reunited with their relatives).

Register-based sampling is on the other hand feasible and adequate in the Spanish case - although its use limits the comparability with sampling efforts in Italy. The remaining challenge in this case is maintaining the costs of surveying a dispersed, relatively mobile and relatively vulnerable population within affordable limits. These problems are compounded by accuracy issues in the register, particularly since (both in the case of Italy and Spain) there is a lack of incentives for immigrants to de-register when they leave the country or change their residence within it. However, two corrective procedures were introduced in Spain in 2007 and 2013, which should have increased the reliability of the registry. In fact, all register-based surveys carried out in Spain following the introduction of these procedures managed to achieve their final numerical targets by applying an exclusively individual random sampling.

Still, non-contact rates remain elevated - since immigrants remain a dispersed, relatively hard-to-reach population, and the Padrón is still not completely accurate either (Miyar Busto, 2011) despite the significant improvements. So different strategies need to be applied in order to maintain the survey costs within reasonable limits. These methodological solutions include: using the household as a sampling unit; selecting areas of high concentration of the target population; clustering by neighbourhood; or introducing flexibility in contacts replacement and number of trips allowed.

The lack of an exhaustive list of the target population (and the inaccessibility of the Anagrafe) has led researchers in Italy to turn to alternative sampling methods which allow including different definitions of migrants (foreign-born) and, in particular, 
undocumented migrants. In the case of Spain, the financial and administrative barriers to draw and implement samples from the Padrón has also led some researchers to apply alternative sampling methods. The application of these methods faces similar challenges in both countries: ensuring the representativeness and unbiased nature of the sample, and again keeping the costs of sampling under control, due in particular to high attrition rates. In this context, and particularly for the case of Italy, the estimates based on the CS methodology seem to be the most accurate and reliable and the response rates are also satisfactory (Fasani, 2008; Mecatti \& Migliorati, 2003; Blangiardo, 2008).

\section{Endnotes}

${ }^{1}$ Note that the Italian figures include only foreign citizens, a less encompassing category than foreign-born people. See discussion below.

${ }^{2}$ EU-citizens constitute $30 \%$ of the foreign residents in Italy (1,5 million) and $32 \%$ of the foreign-born residents in Spain (1,9 million).

${ }^{3}$ In Italy, both informal processes (in 1986, 1990, 1994, 1998, 2002 and 2006) and formal ones (in 2009 and 2012) have taken place. In Spain, extraordinary regularization processes took place in 1986, 1991/1992, 1996, 2000, 2001, and 2005.

${ }^{4}$ Data on foreign-born population is only available in Italy from the decennial census data.

${ }^{5} \mathrm{EU}$ citizens do not require a residence permit to stay in Italy (or Spain), but they must enroll in the Anagrafe (and the Central Registry of Foreigners and Padrón in the case of Spain), when they decide to stay for more than three months. After 5 years, they can apply for the residence card.

${ }^{6}$ In addition, a similar number of foreigners were still in the Padrón but deactivated by INE for statistical purposes due to their unclear status (see González-Ferrer, 2009).

${ }^{7}$ Since obtaining the permit is not simple or immediate, and this is even more the case when applying (a housing accommodation is mandatory) short-term migrants tend to end up included in irregular or unregistered population.

${ }^{8}$ Apart from the ENI2007, INE has not carried out any other survey that focused on the immigrant population but has opted instead by including immigrants as part of the overall sampling design of general surveys, which implies some limitations often related to their small sample sizes.

${ }^{9}$ Even this strategy was not sufficient to attain the targeted sample size within the expected calendar, so eventually spatial sampling and random routes were also used to complete the sample (see Alternative sampling methods for immigrants in Spain and Italy).

${ }^{10}$ Although in principle the official population figures were expected to be cleaned and published in early 2006, the period allowing foreigners affected by the expiry procedure to renew their registration had to be extended and the official cleaned-up figures were not ready until November 2006 (http://www.ine.es/prensa/np447.pdf)

${ }^{11}$ MESE stands for the Spanish name of the Project "Migrations between Senegal and Spain", directed by Pau Baizán, funded by the Spanish Ministry of Science and Innovation (CSO2009-12816). The MESE survey followed the experience of the MAFE Survey in 2008. Detailed information at http://mafeproject.site.ined.fr/en/.

${ }^{12}$ Note that this is the longest questionnaire of all surveys with immigrants reviewed in this article (see Table 2). The questionnaire collected information on respondents' life trajectories in different dimensions (migration, partners, fertility, migration networks, labour, 
properties, legal status, etc.) year by year, since the date of birth until the date of the interview. The questionnaires are available at http://mafeproject.site.ined.fr/en/.

${ }^{13}$ Before discarding an individual, the interviewers had to attempt four visits, one during the weekend and one after $8 \mathrm{pm}$, in order to maximize the chances of locating the sampled individuals in their homes at some point, and not introducing biases.

${ }^{14}$ In MESE, approximately half of the contacts from the Padrón list resulted in noncontact, compared to $43-47 \%$ in ICS (for Barcelona and Madrid, respectively), 45\% in ISSP 2012 and 57\% in ISSP 2014.

${ }^{15}$ It is highly likely that the good results obtained, despite the specific challenges, are related to some of the specific strategies developed in the implementation of the fieldwork, including: multiple information channels (i.e. letter sent to the domiciles, leaflets, free-call telephone number and email), which helped to build trust, identify specific needs, facilitate contacts and reduce wasted visits; careful selection and training of interviewers, including one Senegalese migrant acting also as mediator; and in-house coordination of the survey for quick evaluation and adjustment of strategies.

${ }^{16}$ For a non-comprehensive but illustrative review of different methods developed in the last decades see Reichel and Morales (2017).

${ }^{17}$ In Spain, the main sampling method was nonetheless register-based.

${ }^{18}$ The non-parametric Kruskal-Wallis and Mann-Withney tests have confirmed that the weight system guarantees the representativeness of the total population by augmenting the representativeness for the most elusive segment of the population (irregular migrants, irregular workers and recently arrived migrants) and solving potential problems of under-coverage for these categories.

${ }^{19}$ To identify the centres, a pilot survey using the 'snow ball sampling' is recommended, in order to to extend the initial short list into a more exhaustive one, until a sufficiently heterogeneous level is achieved. For full details on the selection procedure and the sampling technique see Baio et al., (2011).

${ }^{20}$ As the waves of immigrants of the same nationality follows one another, and the integration process develops, these lists change and the number of centres may decrease, reflecting lower needs for immigrants to remain close to their country fellows. In contrast, when completely new groups arrive, the number of centres grows, including many temporary small spots which are hardly detectable at the early stage of the immigration.

\section{Acknowledgements}

The research leading to these results has received funding from the European Union's Seventh Framework Programme (FP7/2007-2013) under grant agreement no. 613468 for the research project TEMPER (Temporary versus Permanent Migration).

\section{Authors' contributions}

All authors contributed to writing sections Introduction, Short description of the immigration to Italy and Spain. ISS and AGF jointly contributed to all Spain-related contents. SR and EBB wrote the sections on Anagrafe. GCB and EBB wrote the sections on alternative sampling methods applied in Italy. ISS wrote the conclusion and re-organized the final draft. All authors read and approved the final manuscript. 


\section{Author details}

${ }^{1}$ National Research Council, CSIC, Albasanz, 26-28, 28037 Madrid, Spain. ${ }^{2}$ Università degli Studi di Milano-Bicocca, Via degli Arcimboldi 8, 20126 Milan, Italy.

Received: 31 January 2017 Accepted: 10 September 2017

Published online: 03 November 2017

\section{References}

Accetturo, A., \& Infante, L. (2013). Skills or culture? An analysis of the decision to work by immigrant women in Italy. IZA Journal of Migration, 2(2), 1-21.

Arango, J. (2000). Becoming a country of immigration at the end of the twentieth century: The case of Spain. In R. King, G. Lazaridis, C. Tzardanidis (Eds.), Eldorado or fortress? Migration in southern Europe, (pp. 253-276). Basingstoke: McMillan.

Arango, J., \& Finotelli, C. (2009). Spain. In M. Baldwin-Edwards, A. Kraler (Eds.), REGINE Regularisations in Europe. Study on practices in the area of regularisation of irregularly staying thirdcountry nationals in the member states of the EU. Vienna: ICMPD.

Baio, G., Blangiardo, G. C., Blangiardo, M. (2011). Centre sampling technique in foreign migration surveys: A methodological note. Journal of Official Statistics, 27, 451-465.

Barbiano di Belgiojoso, E., \& Rimoldi, S. (2007). Recenti stime della presenza straniera in Italia: metodologia e risultati [Recent estimates on foreign population in Italy: methodologies and results]. Latina: Paper presented at "Giornate di Studio sulla Popolazione 2007".

Beauchemin, C. (2012). Migrations between Africa and Europe: Rationale for a survey design MAFE methodological note, (p. 5).

Beauchemin, C., \& González-Ferrer, A. (2011). Sampling international migrants with origin-based snowballing method. New evidence on biases and limitations. Demographic Research, 25(3), 103-134. https://doi.org/10.4054/DemRes. 2011.25.3.

Birindelli, A. M., Blangiardo, G., Bonifazi, C., Caruso, M. G., Cesarini Sforza, L. Farina, P., ... Terzera, L. (2000). Push and pull factors of international migration: country report for Italy (Working paper population and social condition, $n$ 5). Eurostat.

Birindelli, A. M., \& Blangiardo, G. C. (2010). The foreigners in italy: Experiences in the field survey research. Rivista Italiana di Economia, Demografia e Statistica, LXIV, 3, 45-56.

Blangiardo, G. C. (1996). II campionamento per centri nelle indagini sulla presenza straniera in Lombardia: una nota metodologica The centres sampling method in the surveys on foreign population in Lombardy Region: the methodology]. In AA.W. [Various authors]. Studi in onore di G. Landenna [Studies in honour to G. Landenna] Giuffrè, Milano.

Blangiardo, G. C. (2008). The centre sampling technique in surveys on foreign migrants. Geneva: The balance of a multiyear experience (Working paper 12 Joint UNECE/Eurostat Work Session on Migration Statistics).

Blangiardo, G. C. (2015). Gli aspetti statistici [Statistical aspects]. In F. Ismu (Ed.), Ventunesimo Rapporto sulle migrazion 2015 [Recent estimates on foreign population in Italy: methodologies and results], (pp. 45-60). Milano: Franco Angeli.

Blangiardo, G. C. (2016). Gli aspetti statistici [Statistical aspects]. In F. Ismu (Ed.), Ventiduesimo Rapporto sulle migrazioni 2016 [Twentysecond Migration report 2016]. Milano: Franco Angeli.

Blangiardo, G. C., \& Farina, P. (2006). I/ Mezzogiorno dopo la grande regolarizzazione Immagini e problematiche dellimmigrazione [The South after the great regularization. Immigration problems], (vol. 3). Milano: Franco Angeli.

Bonifazi, C. (2013). L'ttalia delle migrazioni [ltaly of migrations]. Bologna: II Mulino.

Casacchia, O., \& Strozza, S. (1990). La stima della presenza straniera clandestina alcuni problemi teorici e operativi [The estimate of illegal foreign population some theoretical and empirical problems]. In M. Natale (Ed.), Economia e popolazione. Alcuni aspetti delle interrelazioni tra sviluppo demografico ed economico [Economy and population. Some aspects of the interrelations between demographic and economic development]. Milano: Franco Angeli.

Cebolla, H., \& González-Ferrer, A. (2008). La inmigración en España (2000-2007). Del control de flujos a la integración de los inmigrantes [Immigration in Spain (2000-2007). From flow control to the integration of immigrants]. Madrid: Centro de Estudios Políticos y Constitucionales.

Cebolla, H., \& González-Ferrer, A. (2013). Inmigración ¿Integración sin modelo? [Immigration: Integration without a model?]. Madrid: Alianza Editorial.

Cesareo, V., \& Blangiardo, G. C. (Eds.) (2009). Indici di Integrazione [Integration Indexes]. Milano: Franco Angeli.

CIS 2012. Estudio 2947. Salud (International Social Survey Programme). Mayo-Julio 2014. Informe Metodológico.

CIS 2014. Estudio 3020. Ciudadanía (International Social Survey Programme). Marzo-Mayo 2014. Informe Metodológico.

Díaz Hernández, R., Domínguez Mujica, J., Parreño Castellano, J. M. (2010). Inmigración Y Ciudad En España: Integración versus Segregación Socio-Territoriales [Immigration and City in Spain: Integration versus Socio-Territorial Segregation]. Scripta Nova, 14.

Domingo, A., \& Blanes, A. (2015). Inmmigración y emigración en España. Estado de la cuestión y perspectivas de futuro. Anuario de la Inmigración en España 2014 [Immigration and emigration in Spain. State of the issue and future prospects. Yearbook of Immigration in Spain 2014], (pp. 94-122). Barcelona: CIDOB.

Duque, I., Ballano, C., Perez, C. (2013). The 2007 Spanish National Immigrant Survey (ENI): Sampling from the Padrón. In J. Font, M. Mendez (Eds.), Surveying ethnic minorities and immigrant populations: Methodological challenges and research strategies, (pp. 69-83). Amsterdam: IMISCOE Research, Amsterdam University Publications.

Fasani, F. (2008). Undocumented migration. Counting the uncountable. Data and trends across Europe. Country Report Italy. Clandestino. European Commission.

González-Ferrer, A. (2009). PROMINSTAT, National Data Collection Systems and practices, Country Report Spain. Retrieved from http://research.icmpd.org/fileadmin/Research-Website/Project_material/PROMINSTAT_File_ Exchange/PROMINSTAT_Spain.pdf

González-Ferrer, A. (2013). La nueva emigración española. Lo que sabemos y lo que no, Zoom Político, 18. Fundación Alternativas [The new Spanish emigration. What we know and what we do not]. Retrieved from http://www. 
fundacionalternativas.org/laboratorio/documentos/zoom-politico/la-nueva-emigracion-espanola-lo-que-sabemos-ylo-que-no

González-Ferrer, A., \& Cortina Trilla, C. (2015). Los nuevos españoles. Inmigración, integración y acceso a la nacionalidad [The new Spaniards. Immigration, integration and access to nationality]. In CIS, España 2015: Situación social, Madrid: Centro de Investigaciones Sociológicas.

Huddleston, T., \& Tjaden, J. D. (2012). Immigrant citizens survey. In How immigrants experience integration in 15 European cities. Brussels: King Baudouin Foundation and the Migration Policy Group.

Ismu, Censis, \& Iprs (2010). Immigrazione e lavoro. Percorsi lavorativi, Centri per limpiego, politiche attive IImmigration and job. Working trajectories, employment centres active policies]. Quaderni Ismu 1/2010.

Istat. (2015, October 22). Retrieved from http://www.Istat.it/it/archivio/171408.

Istat. (2016, October 6). Condizione e Integrazione sociale dei Cittadini Stranieri 2011-2012. Aspetti metodologici dell'indagine [Social condition and integration of foreign citizens 2011-2012. Survey methodological note]. Retrieved from http://www.lstat.it/en/archive/191097. Accessed September 20, 2016.

Istat. (n.d.). Demographic Statistics. Retrieved from http://demo.istat.it/.

Izaguirre Vizcaya, M., González Ferrer, A., Font, J., Cases, J. I., Arenal Pérez, C., Myrem, A., ... Méndez, M. (2016). Remesas e inclusión financiera: Análisis de una encuesta de migrantes de América Latina y el Caribe en España [Remittances and financial inclusion: Analysis of a survey of migrants from Latin America and the Caribbean in Spain].

Jacobs, D., Swyngedouw, M., Hanquinet, L., Vandezande, V., Andersson, R., Beja Horta, A. P., Berger, M. (2009). The challenge of measuring immigrant origin and immigration-related ethnicity in Europe. Journal of International Migration and Integration, 10(1), 67-88. https://doi.org/10.1007/s12134-009-0091-2.

Kraler, A., \& Vogel, D. (Eds.). 2008. Undocumented Migration: Counting the Uncountable. Data and Trends Across Europe. Report on methodological issues, Clandestino, European Commission. Retrieved from http:// irregularmigration.net/typo3_upload/groups/31/4.Background_Information/4.1.Methodology/Methodological_ Issues_Clandestino_Report_Nov09_2.pdf. Accessed September 30, 2016

Martín-Pérez, A., \& Moreno-Fuentes, F. J. (2012). Migration and Citizenship Law in Spain: Path-dependency and Policy Change in a Recent Country of Immigration. International Migration Review, 46(3), 625-655.

McKenzie, D. J., \& Mistiaen, J. (2009). Surveying migrant households: A comparison of census-based, snowball and intercept point surveys. Journal of the Royal Statistical Society, 172(Part 2), 339-360.

Mecatti, F., \& Migliorati, S. (2003). Centre sampling: A strategy for elusive population surveys. Statsitica LXIII, 3, 537-560.

Méndez, M., \& Font, J. (2013). Surveying immigrant populations: Methodological strategies, good practices and open questions. In J. Font, \& M. Méndez (Eds.), Surveying ethnic minorities and immigrant populations. Methodological challenges and research strategies, Imiscoe research. Amsterdam: Amsterdam University Press.

Ministerio de Empleo y Seguridad Social. (n.d.) Retrieved from http://extranjeros.empleo.gob.es/es/Estadisticas/index.html

Miyar Busto, M. (2011). La Dinámica De La Inmigración En España: Una Década De Llegadas Y Salidas [The Dynamics of Immigration in Spain: A Decade of Arrivals and Departures]. (Doctoral Dissertation). Universidad Nacional de Educación a Distancia

Morales, L., Anduiza, E., Rodríguez, E., San Martín, J. (2008). Capital social, pautas identitarias y actitudes hacia 'los otros': la incorporación cívica de la población de origen inmigrante en Barcelona y Madrid [Social capital, identity patterns and attitudes toward 'others': the civic incorporation of the immigrant population in Barcelona and Madrid]. Panorama Social, 8(2), 119-142.

Morales, L., Martínez, V., Méndez, M. (2012). The immigrant citizens' survey in Spain: Description of the methodology and fieldwork procedures. University of Leicester and CIS.

Morales, L., \& Pilati, K. (2014). The political transnationalism of Ecuadorians in Barcelona, Madrid and Milan. Global Networks, 1(2014), 80-102.

Morales, L., \& Ros, V. (2013). Comparing the response rates of autochthonous and migrant populations in nominal sampling surveys: The LOCALMULTIDEM study in Madrid. In J. Font, M. Mendez (Eds.), Surveying ethnic minorities and immigrant populations: Methodological challenges and research strategies, (pp. 147-172). Amsterdam: IMISCOE Research, Amsterdam University Publications.

Natale, M., \& Strozza, S. (1997). Gli immigrati stranieri in Italia [Foreign immigrants in Italy]. Bari: Cacucci Editore.

National Statistical Institute, INE. (n.d.) Retrieved from http://www.ine.es

Obućina, O. (2013). Occupational trajectories and occupational cost among Senegalese immigrants in Europe. Demographic Research, 28(19), 547-580.

Reichel, D., \& Morales, L. (2017). Surveying immigrants without sampling frames - Evaluating the success of alternative field methods. Comparative Migration Studies, 5, 1 .

Reyneri, E. (1998). The role of the underground economy in irregular migration to Italy: Cause or effect? Journal of Ethnic and Migration Studies, 24(2), 313-331.

Ródenas, C. (2012). Buenas noticias para el Padrón (de parte del Censo de 2011) [Good news for the Padrón (from the 2011 Census)]. Retrieved from https://blogaldeaglobal.com/2012/12/17/buenas-noticias-para-el-padron-de-partedel-censo-de-2011-por-carmen-rodenas-universidad-de-alicante/

Sandu, D. (2009). Romanian communities in Spain. Retrieved from http://www.fundatia.ro/sites/default/files/en_82_ ROMANIAN\%20COMMUNITIES\%20IN\%20SPAIN.pdf

Strozza, S. (2004). Estimates of the irregular foreigners in Italy: A review of the literature. International Migration Review, 38(1), 309-331.

Strozza, S., Natale, M., Todisco, E., Ballacci, F. (2002). La rilevazione delle migrazioni internazionali e la predisposizione di un sistema informativo sugli stranieri [International migration surveys and the set of an information system on foreigners]. Roma: Presidenza del Consiglio dei Ministri - Commissione per la garanzia dell'informazione statistica, rapporto di ricerca [Presidency of the Council of Ministers - Committee for the statistical information guarantee, research report].

Vogel, D., \& Kovacheva, V. (2008). Classification report: Quality assessment of estimates on stocks of irregular migrants (Working paper 1/2008). Hamburg Institute of International Economics. 